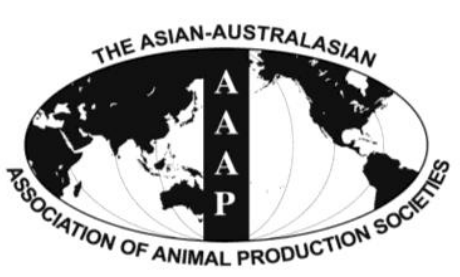

Open Access

Asian Australas. J. Anim. Sci.

Vol. 27, No. 4 : 600-607 April 2014

http://dx.doi.org/10.5713/ajas.2013.13537

www.ajas.info

pISSN 1011-2367 elSSN 1976-5517

\title{
Effects of Substrate to Inoculum Ratio on the Biochemical Methane Potential of Piggery Slaughterhouse Wastes
}

\author{
Young-Man Yoon, Seung-Hwan Kim, Kook-Sik Shin, and Chang-Hyun Kim ${ }^{1}$ * \\ Biogas Research Center, Hankyong National University, Anseong, Gyeonggi, 456-749, Korea
}

\begin{abstract}
The aim of this study was to assess the effect of substrate to inoculum ratio ( $\mathrm{S} / \mathrm{I}$ ratio) on the biochemical methane potential (BMP) and anaerobic biodegradability $\left(\mathrm{D}_{\mathrm{deg}}\right)$ of different piggery slaughterhouse wastes, such as piggery blood, intestine residue, and digestive tract content. These wastes were sampled from a piggery slaughterhouse located in Kimje, South Korea. Cumulative methane production curves for the wastes were obtained from the anaerobic batch fermentation having different $\mathrm{S} / \mathrm{I}$ ratios of $0.1,0.5,1.0$, and 1.5. BMP and anaerobic biodegradabilities $\left(\mathrm{D}_{\mathrm{deg}}\right)$ of the wastes were calculated from cumulative methane production data for the tested conditions. At the lowest S/I ration of 0.1, BMPs of piggery blood, intestine residue, and digestive tract content were determined to be $0.799,0.848$, and $1.076 \mathrm{Nm}^{3} \mathrm{~kg}^{-1}-\mathrm{VS}_{\text {added }}$, respectively, which were above the theoretical methane potentials of 0.539 , 0.644 , and $0.517 \mathrm{Nm}^{3} \mathrm{~kg}^{-1}-\mathrm{VS}_{\text {added }}$ for blood, intestine residue, and digestive tract content, respectively. However, BMPs obtained from the higher S/I ratios of $0.5,1.0$, and 1.5 were within the theoretical range for all three types of waste and were not significantly different for the different S/I ratios tested. Anaerobic biodegradabilities calculated from BMP data showed a similar tendency. These results imply that, for BMP assay in an anaerobic reactor, the S/I ratio of anaerobic reactor should be above 0.1 and the inoculum should be sufficiently stabilized to avoid further degradation during the assay. (Key Words: S/I Ratio, Biochemical Methane Potential, Piggery Slaughterhouse Waste, Anaerobic Digestion)
\end{abstract}

\section{INTRODUCTION}

With the growth of the livestock industry in South Korea, increasing quantities and varieties of waste biomass are generated in farms and slaughterhouses. In particular, animal byproducts from slaughterhouses are classed as industrial organic wastes and must be strictly managed according to governmental regulations. Waste products from the pig slaughtering process consist mainly of three components: blood, intestine residue, and digestive tract content. Blood and intestine residues have a high solid content composed of animal protein and fat, while digestive tract contents are composed of vegetable materials, mainly

\footnotetext{
* Corresponding Author: Chang-Hyun Kim. Tel: +82-31-6705095, Fax: +82-31-670-5099, E-mail: kimch@hknu.ac.kr

1 Department of Animal Life and Environment Science, Hankyong National University, Anseong, Gyeonggi, 456-749, Korea.

Submitted Aug. 29, 2013; Accepted Oct. 28, 2013; Revised Nov. 21, 2013
}

carbohydrates originating from corn feedstock (Kim et al., 2011). These organic wastes have been used as ingredients for animal feedstock or compost, but have recently been considered as good substrates for methane production by anaerobic digestion. However, high organic loading can result in various inhibitory effects during anaerobic digestion due to the accumulation of $\mathrm{NH}_{4}{ }^{+} \mathrm{N}$ from protein decomposition, long chain fatty acids from fat, and volatile fatty acids (VFAs) (Salminen et al., 2003; Luste et al., 2009; Palatsi et al., 2010)

Anaerobic digestion processes are widely used for the biological degradation of concentrated organic wastes and for biogas production. These processes involve several complex biological reactions regulated by symbiotic microbial consortia. The methane yield from organic material is thus the result of anaerobic microbial activity, and depends on the composition and characteristics of the crude ingredients (protein, fat, carbohydrate, lignin, etc.), and the levels of any inhibitory factors generated during the digestion process (Angelidaki and Ahring, 1992). 
Biochemical methane potential (BMP) assay is used to determine the methane yield from organic material by using an anaerobic batch reactor. It is expressed as methane produced per unit of volatile solid (VS) content or per unit of chemical oxygen demand (COD) content at standard temperature and pressure. Because the BMP of the organic material is very important in the design, installation, and operation of an anaerobic digester, many researchers have proposed comprehensive protocols for its determination (Owens and Chynoweth, 1993; Angelidaki and Sanders, 2004; Hansen et al., 2004; Angelidaki et al., 2009). BMP determination for different organic wastes is necessary because the anaerobic degradation process is highly influenced by the inherent substrate characteristics of the organic materials. For this reason, specific studies on the effect of substrate to inoculum (S/I) ratio for various organic wastes have been carried out (Chynoweth et al., 1993; Lin et al., 1999; Neves et al., 2004; Rapaso et al., 2006).

$\mathrm{S} / \mathrm{I}$ ratio can be expressed as the amount of VS in the substrate per the amount of VS or amount of volatile suspended solid (VSS) originating from inoculum. Chynoweth et al. (1993) reported that maximal methane yields were obtained with $\mathrm{S} / \mathrm{I}$ ratios of 0.5 to 1.0 in anaerobic batch digestion of herbaceous and woody feedstock and municipal wastes. In addition, Hashimoto (1989) found that methane yields were lower at S/I ratios higher than 4.0 in a study on the influence of $S / I$ ratio on BMP in wheat straw, using 20 different S/I ratios (0.03 to 10.91). Although $S / I$ ratio highly influences methane yields from organic wastes, many BMP measurements for various feedstocks were made without considering the $\mathrm{S} / \mathrm{I}$ ratio. The purpose of this study was to assess the effects of $\mathrm{S} / \mathrm{I}$ ratios on BMPs and anaerobic biodegradability for animal byproducts from piggery slaughterhouses in their use as alternative sources for biogas production.

\section{MATERIALS AND METHODS}

\section{Substrates and inoculum}

The wastes used in this study were collected from a pig slaughterhouse in Kimje, South Korea, which processes about 20,000 pigs (115 kg per live pig) per month. Samples were collected from the bleeding (blood), evisceration (intestine residue), and washing (digestive tract content) steps of the slaughtering process. Inoculum was collected from a farm-scale biogas plant (Anseong, South Korea) that digests piggery slurry. The anaerobic inoculum was passed through a $2 \mathrm{~mm}$ sieve and kept at a mesophilic temperature $\left(38^{\circ} \mathrm{C}\right)$ for one week to remove any remaining biodegradable fraction. Inoculum characteristics are shown in Table 1 .
Table 1. Anaerobic inoculum characteristics

\begin{tabular}{lc}
\hline Parameters & Inoculum \\
\hline $\mathrm{pH}$ & 8.4 \\
$\mathrm{TS}(\mathrm{g} / \mathrm{L})$ & $17.0 \pm 0.477^{1}$ \\
$\mathrm{VS}(\mathrm{g} / \mathrm{L})$ & $10.6 \pm 0.399$ \\
$\mathrm{TKN}(\mathrm{g} / \mathrm{L})$ & $5.1 \pm 0.246$ \\
$\mathrm{NH}_{4}{ }^{-}-\mathrm{N}(\mathrm{g} / \mathrm{L})$ & $3.4 \pm 0.033$ \\
Alkalinity $\left(\mathrm{g} / \mathrm{L}\right.$ as $\left.\mathrm{CaCO}_{3}\right)$ & $6.9 \pm 0.208$ \\
\hline
\end{tabular}

${ }^{1}$ Standard error.

\section{BMP assay}

Anaerobic methane production was measured by batch BMP assay under mesophilic conditions $\left(38^{\circ} \mathrm{C}\right)$. Substrate to inoculum ratios (S/I ratios) for BMP assay cultures were prepared based on the VS content of substrate and inoculum, as shown in Table 2 . The four different $\mathrm{S} / \mathrm{I}$ ratios tested $(0.1$, $0.5,1.0$, and 1.5) were prepared while maintaining a constant VS concentration (10.56 g-VS/L) and volume $(60.0 \mathrm{~mL})$ at inoculum input, varying the amounts of solid substrate added to BMP assay vials over the ranges of 0.372 to $5.584 \mathrm{~g}$ for blood, 0.247 to $3.706 \mathrm{~g}$ for intestine residue, and 0.250 to $3.748 \mathrm{~g}$ for digestive tract content. BMP assays were carried out in a working volume of about $60 \mathrm{~mL}$ in a $160 \mathrm{~mL}$ serum bottle. The head space was filled with $\mathrm{N}_{2}$ gas, and the bottle sealed with a butyl rubber stopper. Three BMP bottles for each sample and blank were incubated for 76 days in a convection incubator, with daily manual mixing. Methane production was corrected for standard temperature and pressure (STP), and BMP $\left(\mathrm{Nm}^{3} / \mathrm{kg}-\mathrm{VS}_{\text {added }}\right)$ was determined per unit of VS in the waste added to each vial.

Cumulative methane production and methane yield, expressed as liters of $\mathrm{CH}_{4}$ and liters of $\mathrm{CH}_{4}$ per $\mathrm{kg}$ of $\mathrm{VS}$, respectively, were assessed using the BMP assay. The maximum specific methane production rate $\left(R_{m}\right)$, lag phase time $(\lambda)$, and methane production potential $(\mathrm{P})$ were determined using the modified Gompertz model (Eq. 1) described by Zwietering et al. (1990) and Lay et al. (1998). The experimental cumulative methane production curve was corrected to account for biogas production in the blank.

Table 2. Experimental conditions used for the BMP assay at different substrate to inoculum $(\mathrm{S} / \mathrm{I})$ ratios

\begin{tabular}{lllll}
\hline \multirow{2}{*}{ Parameters } & \multicolumn{4}{c}{ S/I ratios } \\
\cline { 2 - 5 } & \multicolumn{1}{c}{0.1} & 0.5 & 1.0 & 1.5 \\
\hline Inoculum & & & & \\
$\quad$ Volume (mL) & 60.0 & 60.0 & 60.0 & 60.0 \\
$\quad$ Volatile solid (g/L) & 10.56 & 10.56 & 10.56 & 10.56 \\
$\quad$ Substrates & & & & \\
$\quad$ Input amount (g) & & & & \\
$\quad$ Blood & 0.372 & 1.861 & 3.722 & 5.584 \\
$\quad$ Intestine residue & 0.247 & 1.236 & 1.471 & 3.706 \\
$\quad$ Digestive tract content & 0.250 & 1.249 & 2.499 & 3.748 \\
$\quad$ Volatile solid (g/L) & 1.056 & 5.280 & 10.560 & 15.840 \\
\hline
\end{tabular}


Ultimate methane potentials $\left(B_{u}\right)$ of the tested samples were calculated as methane production potential $(\mathrm{P})$ per $\mathrm{kg}$ of VS. The modified Gompertz model (Eq. 1) used to fit the cumulative methane production data is as follows:

$$
\mathrm{M}=\mathrm{P} \times \exp \left\{-\exp \left[\mathrm{R}_{\mathrm{m}} \times \mathrm{e} / \mathrm{P} \times(\lambda-\mathrm{t})+1\right]\right\} \quad \text { Eq. } 1
$$

where $\mathrm{M}$ is cumulative methane production $(\mathrm{mL})$; e is $\exp (1) ; \mathrm{R}_{\mathrm{m}}$ is the maximum specific methane production rate $(\mathrm{mL} / \mathrm{d}) ; \mathrm{P}$ is methane production potential $(\mathrm{mL}) ; \lambda$ is lag phase time (days). The degree of anaerobic degradation $\left(D_{\text {deg }}=B_{\mathrm{u}} / \mathrm{B}_{\mathrm{th}} \times 100\right)$ was defined as the ultimate methane potential $\left(\mathrm{B}_{\mathrm{u}}\right)$ obtained from the BMP assay in relation to the theoretical biochemical methane potential $\left(\mathrm{B}_{\mathrm{th}}\right)$. Methane yields and biodegradability data for the piggery slaughterhouse wastes were compared after single factor statistical significance analysis using Duncan's multiple range test (0.05 level).

\section{Analytical procedures}

Total solid (TS), volatile solid (VS), $\mathrm{pH}$, soluble chemical oxygen demand (SCOD), total chemical oxygen demand (TCOD), total nitrogen (TN), ammonium nitrogen $\left(\mathrm{NH}_{4}{ }^{+}-\mathrm{N}\right)$, total phosphorus (TP), and alkalinity were determined by standard methods (APHA, 1998). Elemental composition $(\mathrm{C}, \mathrm{H}, \mathrm{N}, \mathrm{O}, \mathrm{S})$ was analyzed using the element analyzer (EA1108, Thermo Finnigan, USA). Crude protein was determined by multiplying total nitrogen values by 6.25 , and crude fat was extracted with ether using the Soxhlet system. The volatile fraction of crude fiber was measured by ignition after boiling for $30 \mathrm{~min}$ with $1.25 \%$ $\mathrm{H}_{2} \mathrm{SO}_{4}$ and then for 30 min with $1.25 \% \mathrm{NaOH}$. Total gas production by BMP assay was measured daily for the first 5 days and subsequently every 2 to 3 days by displacement of an acidified brine solution in a burette, recording the volume of displaced solution after correcting for atmospheric pressure (Beuvink et al., 1992; Williams et al., 1996). To investigate the gas composition, $\mathrm{CH}_{4}$ and $\mathrm{CO}_{2}$ concentrations in gas samples were determined by a gas chromatograph (Clarus 680, PerkinElmer, USA) equipped with a thermal conductivity detector and HayeSepQ packed column (CRS Inc., USA). The column was operated with helium as carrier gas at a constant flow rate of $5 \mathrm{~mL} / \mathrm{min}$. The injector was maintained at $150^{\circ} \mathrm{C}$, the oven was set at $90^{\circ} \mathrm{C}$, and the detector was set at $150^{\circ} \mathrm{C}$.

\section{Theoretical methane potential}

The chemical compositions of substrates were determined from elemental analysis data, and theoretical methane potential $\left(\mathrm{B}_{\mathrm{th}}\right)$ was estimated based upon the stoichiometry of the degradation reaction using Buswell's formula (Boyle, 1976) (Eq. 2).

$$
\begin{aligned}
& \mathrm{C}_{\mathrm{a}} \mathrm{H}_{\mathrm{b}} \mathrm{O}_{\mathrm{c}} \mathrm{N}_{\mathrm{d}} \mathrm{S}_{\mathrm{e}}+(\mathrm{a}-\mathrm{b} / 4-\mathrm{c} / 2+3 \mathrm{~d} / 4+\mathrm{e} / 2) \mathrm{H}_{2} \mathrm{O} \rightarrow \\
& \quad(\mathrm{a} / 2+\mathrm{b} / 8-\mathrm{c} / 4-3 \mathrm{~d} / 8-\mathrm{e} / 4) \mathrm{CH}_{4} \\
& \quad+(\mathrm{a} / 2-\mathrm{b} / 8+\mathrm{c} / 4+3 \mathrm{~d} / 8+\mathrm{e} / 4) \mathrm{CO}_{2}+\mathrm{dNH}_{3}+\mathrm{eH}_{2} \mathrm{~S} \quad \text { Eq. } 2
\end{aligned}
$$

The $\mathrm{B}_{\text {th }}$ in terms of normal cubic meters per VS content $\left(\mathrm{Nm}^{3}-\mathrm{CH}_{4} / \mathrm{kg}-\mathrm{VS}_{\text {added }}\right)$ under standard conditions $\left(0^{\circ} \mathrm{C}, 1\right.$ atm) was calculated from Eq. 3.

$$
\begin{aligned}
\mathrm{B}_{\text {th }}\left(\mathrm{Nm}^{3} / \mathrm{kg}-\mathrm{VS}_{\text {added }}\right) \\
=22.4 \times\{[(4 \mathrm{a}+\mathrm{b}-2 \mathrm{c}-3 \mathrm{~d}-2 \mathrm{e}) / 8] \\
\quad /(12 \mathrm{a}+\mathrm{b}+16 \mathrm{c}+14 \mathrm{~d}+32 \mathrm{e})\}
\end{aligned}
$$

Eq. 3

\section{RESULTS AND DISCUSSION}

\section{Characteristics of substrates}

The characteristics of the piggery slaughterhouse wastes (blood, intestine residue, and digestive tract content) are shown in Table 3. Blood had $180.0 \mathrm{~g} / \mathrm{kg}$-TS, of which $93 \%$ was protein; intestine residues contained $297.5 \mathrm{~g} / \mathrm{kg}-\mathrm{TS}$, of which $40.1 \%$ was protein and $15.3 \%$ was fat. Digestive tract content, consisting of vegetable materials remaining in the digestive tract, was $297.4 \mathrm{~g} / \mathrm{kg}$-TS that was $15.1 \%$ protein and $6.6 \%$ fiber. VS contents were 170.2 (blood), 256.4 (intestine residue), and 253.6 (digestive tract content) $\mathrm{g} / \mathrm{kg}$, with VS to TS as $94.6 \%, 86.2 \%$, and $85.3 \%$, respectively. Hejnfelt and Angelidaki (2009) studied the anaerobic digestion of piggery slaughterhouse byproducts, reporting that the TS and VS of blood were $17.9 \%$ and $16.8 \%$, and the internal byproduct had $49.1 \%$ TS and $36.6 \%$ VS. Rodríguez-Abalde et al. (2011) reported TS (50.7\%) and VS $(48.9 \%)$ contents higher than those in this study in a mixture of internal organs and piggery fatty wastes. The higher water content of the intestine residue and digestive tract content used in this study was because these byproducts were produced in the slaughterhouse adjacent to the washing process.

\section{Methane production}

Figure 1,2, and 3 show cumulative methane production ( $\mathrm{mL}$ in STP) and methane yield $\left(\mathrm{Nm}^{3} / \mathrm{kg}-\mathrm{VS}_{\text {added }}\right)$ from blood waste, intestine residue, and digestive tract content during anaerobic fermentation at different $\mathrm{S} / \mathrm{I}$ ratios. Cumulative methane production at the lowest $\mathrm{S} / \mathrm{I}$ ratio $(0.1)$ for all piggery slaughterhouse wastes showed the lowest methane production, with production increasing as the S/I ratio rose from 0.1 to 1.5 with increased VS addition.

Cumulative methane production from blood containing high protein $(93.0 \%)$ and digestive tract content containing high $(64 \%)$ nitrogen-free extracts (NFE, mostly non-fiber carbohydrates; data not shown in Table 2) followed exponential type curves from initial fermentation time in the batch anaerobic digestions at all S/I ratios. However, intestine residues containing a high fat content (15.3\%) 
Table 3. Characteristics of piggery slaughterhouse wastes

\begin{tabular}{|c|c|c|c|c|}
\hline \multicolumn{2}{|l|}{ Parameters } & Blood & Intestine residue & Digestive tract content \\
\hline \multicolumn{2}{|l|}{$\mathrm{TS}(\mathrm{g} / \mathrm{kg})$} & $180.0 \pm 0.3^{1}$ & $297.5 \pm 17.1$ & $297.4 \pm 11.4$ \\
\hline \multicolumn{2}{|l|}{ VS (g/kg) } & $170.2 \pm 0.3$ & $256.4 \pm 8.3$ & $253.6 \pm 21.4$ \\
\hline \multicolumn{2}{|l|}{$\mathrm{TN}(\mathrm{g} / \mathrm{kg})$} & $148.8 \pm 0.3$ & $64.2 \pm 5.7$ & $24.1 \pm 1.5$ \\
\hline \multicolumn{2}{|l|}{$\mathrm{NH}_{4}{ }^{+}-\mathrm{N}(\mathrm{g} / \mathrm{kg})$} & $13.9 \pm 0.1$ & $4.1 \pm 0.8$ & $0.5 \pm 0.3$ \\
\hline \multicolumn{2}{|l|}{ Fat $(w / w, \%)$} & $1.1 \pm 0.1$ & $15.3 \pm 0.2$ & $4.0 \pm 0.1$ \\
\hline \multicolumn{2}{|l|}{ Fiber (w/w, \%) } & $0.4 \pm 0.1$ & $2.8 \pm 0.1$ & $6.6 \pm 1.0$ \\
\hline \multicolumn{2}{|l|}{ Protein (w/w, \%) } & $93.0 \pm 0.2$ & $40.1 \pm 3.6$ & $15.1 \pm 1.0$ \\
\hline \multirow{5}{*}{$\begin{array}{l}\text { Elemental } \\
\text { composition (w/w, \%) }\end{array}$} & $\mathrm{C}$ & 48.3 & 53.2 & 36.7 \\
\hline & $\mathrm{H}$ & 9.0 & 7.1 & 5.3 \\
\hline & $\mathrm{O}$ & 24.8 & 20.8 & 29.2 \\
\hline & $\mathrm{N}$ & 14.9 & 6.4 & 1.7 \\
\hline & $\mathrm{S}$ & 0.4 & 0.4 & $\operatorname{Tr}$ \\
\hline \multicolumn{2}{|l|}{$\mathrm{K}(\mathrm{g} / \mathrm{kg})$} & 0.118 & 0.368 & 0.195 \\
\hline \multicolumn{2}{|l|}{$\mathrm{Ca}(\mathrm{g} / \mathrm{kg})$} & 1.221 & 1.482 & 2.018 \\
\hline \multicolumn{2}{|l|}{$\mathrm{Mg}(\mathrm{g} / \mathrm{kg})$} & 224.8 & 138.3 & 371.4 \\
\hline \multicolumn{2}{|l|}{$\mathrm{Na}(\mathrm{g} / \mathrm{kg})$} & 0.094 & 0.238 & 0.155 \\
\hline \multicolumn{2}{|l|}{$\mathrm{Fe}(\mathrm{g} / \mathrm{kg})$} & 0.368 & 0.336 & 0.608 \\
\hline \multicolumn{2}{|l|}{ Co $(\mathrm{mg} / \mathrm{kg})$} & 0.1 & 0.1 & $\operatorname{Tr}$ \\
\hline \multicolumn{2}{|l|}{$\mathrm{Ni}(\mathrm{mg} / \mathrm{kg})$} & 1.6 & 3.0 & 2.7 \\
\hline \multicolumn{2}{|l|}{ Mo $(\mathrm{mg} / \mathrm{kg})$} & ND & ND & ND \\
\hline \multicolumn{2}{|l|}{$\mathrm{Cu}(\mathrm{mg} / \mathrm{kg})$} & 14.6 & 5.1 & 24.0 \\
\hline \multicolumn{2}{|l|}{$\mathrm{Zn}(\mathrm{mg} / \mathrm{kg})$} & 13.0 & 14.9 & 21.4 \\
\hline
\end{tabular}

${ }^{1}$ Standard error. $\mathrm{Tr}=$ Trace. $\mathrm{ND}=$ Not detected.

showed sigmoid type curves with increasing S/I ratio. Further, lag phase times $(\lambda)$, estimated from the methane production data by optimization using the modified Gompertz equation, were considerably prolonged to 4.3 , 21.7, and 26.9 days for S/I ratios of $0.50,1.00$, and 1.5, respectively, as substrate addition was increased (Table 4). Vavilin et al. (2008) reported that methane production could be delayed in the initial digestion period because the particle disintegration and hydrolysis steps that are rate

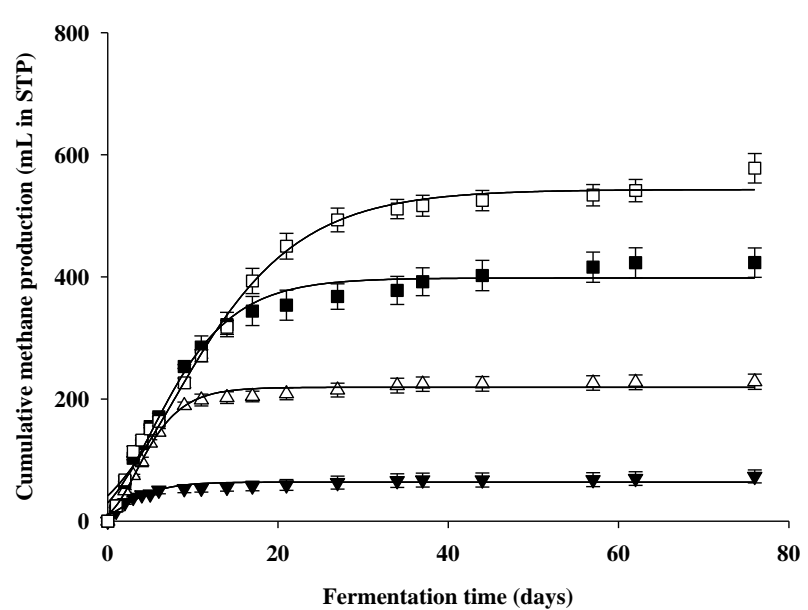

determining in the anaerobic digestion process were highly affected by microbial growth retardation. Moreover, as the hydrolysis of fats and oils to glycerol and long chain fatty acids (LCFAs) proceeded, LCFAs accumulated, often hindering the anaerobic digestion of fatty materials because of their inhibitory effects (Angeldidaki and Aring, 1992). These prolonged lag phase times could be caused by the high fat content in the substrate to which the inoculum had not been previously exposed and adapted.

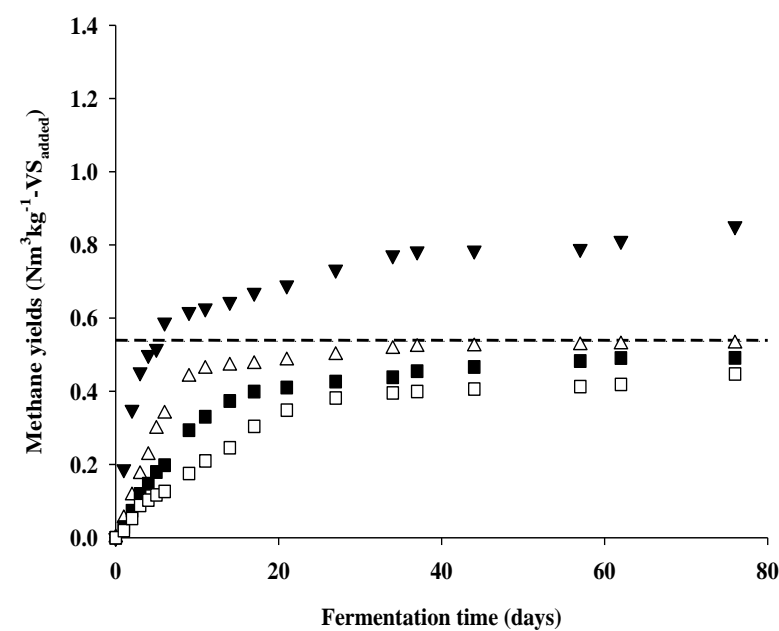

Figure 1. Cumulative methane production and yield from blood during batch anaerobic digestion at different $\mathrm{S} / \mathrm{I}$ ratios. $\boldsymbol{\nabla}, \Delta, \boldsymbol{\square}$, and $\square$ indicate substrate to inoculum (S/I) ratios of $0.10,0.50,1.00$, and 1.50 , respectively, and --- is $\mathrm{B}_{\text {th }}\left(0.539 \mathrm{Nm}^{3} / \mathrm{kg}-\mathrm{VS}_{\text {added }}\right)$. Vertical bars indicate standard deviations. 

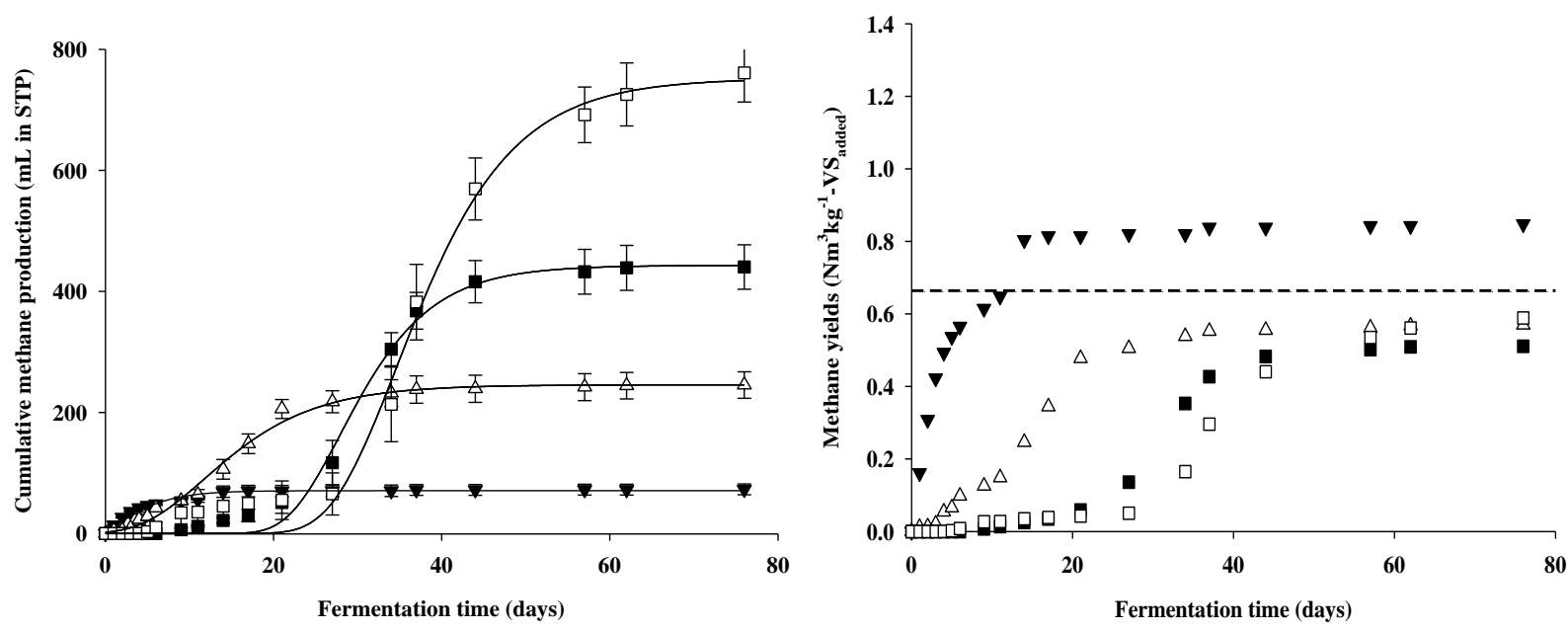

Figure 2. Cumulative methane production and yield for intestine residue during batch anaerobic digestion at different $\mathrm{S} / \mathrm{I}$ ratios. $\boldsymbol{\nabla}, \Delta, \mathbf{\square}$, and $\square$ indicate substrate to inoculum (S/I) ratios of $0.10,0.50,1.00$, and 1.50 , respectively, and --- is $\mathrm{B}_{\mathrm{th}}\left(0.664 \mathrm{Nm}^{3} / \mathrm{kg}-\mathrm{VS}_{\text {added }}\right)$. Vertical bars indicate standard deviations.

The maximum specific methane production rate $\left(\mathrm{R}_{\mathrm{m}}\right)$ generally showed a tendency to increase along with the rise of S/I ratio for the piggery intestine residue and the digestive tract content. $\mathrm{R}_{\mathrm{m}}$ for intestine residue increased from $7.3 \mathrm{~mL} / \mathrm{d}$ for a $0.1 \mathrm{~S} / \mathrm{I}$ ratio to $35.6 \mathrm{~mL} / \mathrm{d}$ for a ratio of 1.50 , and that for the digestive tract content increased from $7.8 \mathrm{~mL} / \mathrm{d}$ for a $0.1 \mathrm{~S} / \mathrm{I}$ ratio to $29.4 \mathrm{~mL} / \mathrm{d}$ for a ratio of 1.50 . In contrast, the $\mathrm{R}_{\mathrm{m}}$ for blood increased to $27.1 \mathrm{~mL} / \mathrm{d}$ at an $\mathrm{S} / \mathrm{I}$ ratio of 1.00 , and thereafter decreased to $24.1 \mathrm{~mL} / \mathrm{d}$ for an $\mathrm{S} / \mathrm{I}$ ratio of 1.50 . This decrease in $\mathrm{R}_{\mathrm{m}}$ at the $1.5 \mathrm{~S} / \mathrm{I}$ ratio could be due to the high protein content of blood waste causing inhibition by ammonia generated during protein degradation. Although ammonia inhibition could be alleviated by acclimation of the microorganisms, a wide range of ammonia concentrations (from 1.7 to $14.0 \mathrm{~g}-\mathrm{N} / \mathrm{L}$ ) has been reported to have inhibitory effects on methane production (Chen et al., 2008).

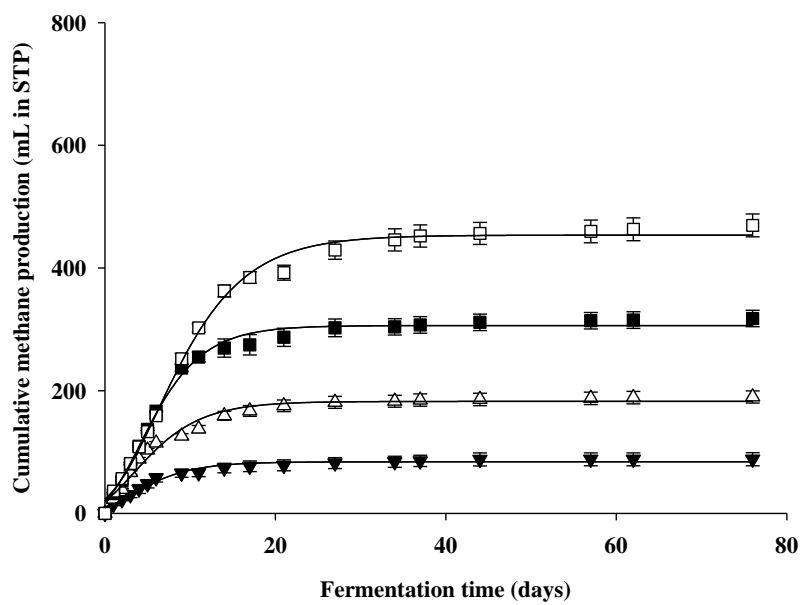

Table 5 shows biochemical methane potentials (BMP), methane production (MP), and anaerobic biodegradability $\left(D_{\text {deg }}\right)$ of piggery slaughterhouse wastes at different S/I ratios. BMPs of blood waste were estimated as $0.799,0.536$, 0.491 , and $0.450 \mathrm{Nm}^{3} / \mathrm{kg}-\mathrm{VS}_{\text {added }}$ for $\mathrm{S} / \mathrm{I}$ ratios of $0.10,0.50$, 1.00 and 1.50 , respectively, and these values decreased with the rise in S/I ratio. Also, BMP values for S/I ratios in the 0.50 to 1.50 range did not differ significantly. The same tendency was seen for piggery intestine residue and digestive tract content. These results have been reported by several researchers. Raposo et al. (2008) analyzed the effect of S/I ratio on BMP for sunflower oil cake, and reported that methane yields decreased from 0.227 to $0.107 \mathrm{Nm}^{3} / \mathrm{kg}$ $\mathrm{VS}_{\text {added }}$ as the $\mathrm{S} / \mathrm{I}$ ratio increased from 0.33 to 2.00 , but they did not observe methane yields in excess of the theoretical methane potential at the lowest S/I ratio $(0.33)$ for a fermentation time of 7 days.

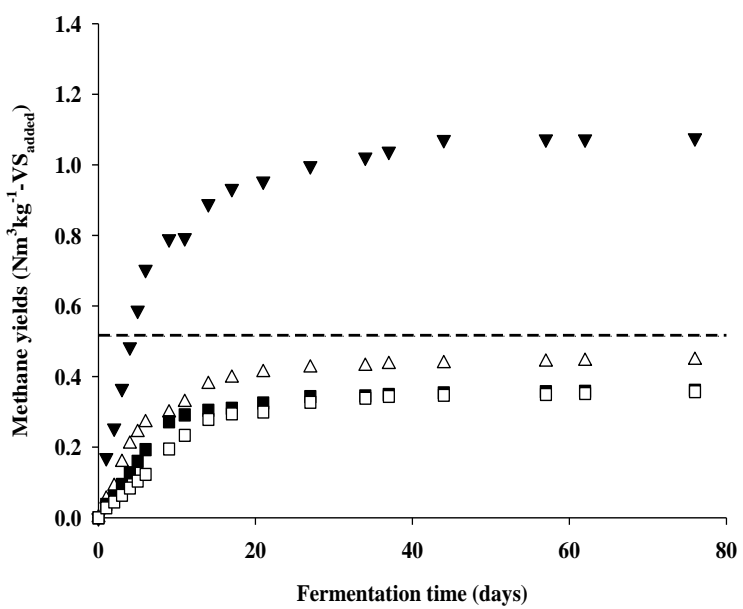

Figure 3. Cumulative methane production and yield from digestive tract contents during batch anaerobic digestion at different $\mathrm{S} / \mathrm{I}$ ratios. $\boldsymbol{\nabla}, \Delta, \mathbf{m}$, and $\square$ indicate substrate to inoculum $(\mathrm{S} / \mathrm{I})$ ratios of $0.10,0.50,1.00$, and 1.50 , respectively, and --- is $\mathrm{B}_{\mathrm{th}}(0.517 \mathrm{Nm} / \mathrm{kg}-$ $\left.\mathrm{VS}_{\text {added }}\right)$. Vertical bars indicate standard deviations. 
Table 4. Parameters obtained by model optimization of cumulative methane production from piggery slaughterhouse wastes at different substrate to inoculum (S/I) ratios

\begin{tabular}{lcrrr}
\hline \multirow{2}{*}{ Parameters } & \multicolumn{5}{c}{ S/I ratios } \\
\cline { 2 - 5 } Blood & 0.10 & 0.50 & 1.00 & 1.50 \\
$\quad \mathrm{P}^{1}(\mathrm{~mL})$ & 63.9 & 219.1 & 398.1 & 543.0 \\
$\mathrm{R}_{\mathrm{m}}{ }^{2}(\mathrm{~mL} / \mathrm{d})$ & 8.4 & 26.8 & 27.1 & 24.1 \\
$\quad \lambda^{3}$ (days) & - & 0.3 & - & - \\
Intestine residue & & & & \\
$\quad \mathrm{P}(\mathrm{mL})$ & 70.7 & 245.7 & 443.0 & 752.1 \\
$\quad \mathrm{R}_{\mathrm{m}}(\mathrm{mL} / \mathrm{d})$ & 7.3 & 12.1 & 26.4 & 35.6 \\
$\quad \lambda(\mathrm{d})$ & - & 4.3 & 21.7 & 26.9 \\
Digestive tract content & \multicolumn{5}{c}{} & \\
$\quad \mathrm{P}(\mathrm{mL})$ & 84.0 & 182.5 & 306.1 & 453.5 \\
$\quad \mathrm{R}_{\mathrm{m}}(\mathrm{mL} / \mathrm{d})$ & 7.8 & 15.3 & 27.5 & 29.4 \\
$\lambda$ (days) & - & - & 0.03 & 0.5 \\
\hline${ }^{1}$ Methane production potential. \\
${ }^{2}$ Maximum specific methane production rate. \\
${ }^{3}$ Lag phase time.
\end{tabular}

The MPs and $D_{\text {deg }}$ for piggery slaughterhouse wastes showed a similar tendency to the results for BMP because they were calculated from BMP data. In particular, the $D_{\text {deg }}$ values were extraordinarily high for blood (148.3\%), intestine residue $(127.7 \%)$, and digestive tract content (208.1\%) at an S/I ratio of 0.1 . For S/I ratios in the 0.50 to 1.50 range, $\mathrm{D}_{\text {deg }}$ for piggery blood, intestine residues, and digestive tract contents were $99.5 \%$ to $83.5 \%, 85.8 \%$ to $77.0 \%$, and $86.3 \%$ to $69.0 \%$, respectively. Liu et al. (2009) performed BMP assays on food waste at S/I ratios of 1.6, 3.1, 4.0 and 5.0 and reported that $\mathrm{D}_{\mathrm{deg}}$ values showed a similar tendency: biodegradability decreased with the rise of S/I ratios, and the highest and lowest VS destruction values $(93.6 \%$ and $54.3 \%)$ were obtained with S/I ratios of
1.6 and 5.0, respectively.

The results of this study revealed that blood, intestine residue, and digestive tract content collected from a piggery slaughterhouse are highly promising substrates for methane production by anaerobic digestion, taking into consideration their chemical characteristics and BMP values. However, methane yields from these wastes at the lowest S/I ratio (0.1) were observed to be greater than the theoretical methane potentials $\left(0.539,0.644\right.$, and $0.517 \mathrm{Nm}^{3} / \mathrm{kg}-\mathrm{VS}_{\text {added }}$ for blood, intestine residue, and digestive tract content, respectively), but were within the theoretical methane potentials yields at the higher $\mathrm{S} / \mathrm{I}$ ratios $(0.5,1.0$, and 1.5) for all piggery slaughterhouse wastes. When anabolic processes for cellular growth and maintenance of anaerobic microorganisms are considered, not all organic materials are directed to methane production in an anaerobic reactor. The degradability of organic materials has therefore been calculated based on the considerations that approximately $7 \%$ of the degraded organic dry weight is used for reformation of bacterial mass (VDI 4360, 2006), and the estimation by Veeken and Hamelers (1999) that an average of $25 \%$ of the energy from substrate is transferred to other sources. Taking these factors into account, the transformable methane production might actually be lower than the theoretical methane potential, and that methane yields determined for the lowest S/I ratio (0.10) might not be unreasonable. Based on these results, we suggest that the proper S/I ratio needs to be tested for BMP assays on different organic wastes. Neves et al. (2004) reported that $\mathrm{S} / \mathrm{I}$ ratio was considered as the major parameter affecting BMP assays, and that inoculum activity should be considered as exhibiting zero order reaction kinetic behavior, while substrate degradation is interpreted using a first order reaction kinetic model. But our results imply that additional degradation of VS in the inoculum could be

Table 5. Methane yield and biodegradability of piggery slaughterhouse wastes in batch anaerobic digestion at different substrate to inoculum $(\mathrm{S} / \mathrm{I})$ ratios

\begin{tabular}{|c|c|c|c|c|}
\hline \multirow{2}{*}{ Parameters } & \multicolumn{4}{|c|}{$\mathrm{S} / \mathrm{I}$ ratios } \\
\hline & 0.10 & 0.50 & 1.00 & 1.50 \\
\hline \multicolumn{5}{|l|}{ Blood } \\
\hline $\mathrm{BMP}^{1}\left(\mathrm{Nm}^{3} / \mathrm{kg}-\mathrm{VS}_{\text {added }}\right)$ & $0.799^{\mathrm{a}}$ & $0.536^{\mathrm{b}}$ & $0.491^{\mathrm{b}}$ & $0.450^{\mathrm{b}}$ \\
\hline $\mathrm{MP}^{2}\left(\mathrm{Nm}^{3} / \mathrm{kg}-\right.$ Substrate $)$ & $0.136^{\mathrm{a}}$ & $0.091^{\mathrm{b}}$ & $0.084^{\mathrm{b}}$ & $0.077^{\mathrm{b}}$ \\
\hline $\mathrm{D}_{\mathrm{deg}}^{3}(\%)$ & $148.3^{\mathrm{a}}$ & $99.5^{\mathrm{b}}$ & $91.1^{\mathrm{b}}$ & $83.5^{\mathrm{b}}$ \\
\hline \multicolumn{5}{|l|}{ Intestine residue } \\
\hline $\operatorname{BMP}\left(\mathrm{Nm}^{3} / \mathrm{kg}-\mathrm{VS}_{\text {added }}\right)$ & $0.848^{\mathrm{a}}$ & $0.569^{\mathrm{b}}$ & $0.511^{\mathrm{b}}$ & $0.589^{\mathrm{b}}$ \\
\hline $\mathrm{MP}\left(\mathrm{Nm}^{3} / \mathrm{kg}\right.$-Substrate $)$ & $0.217^{\mathrm{a}}$ & $0.146^{\mathrm{b}}$ & $0.131^{\mathrm{b}}$ & $0.151^{\mathrm{b}}$ \\
\hline $\mathrm{D}_{\mathrm{deg}}(\%)$ & $127.7^{\mathrm{a}}$ & $85.8^{\mathrm{b}}$ & $77.0^{\mathrm{b}}$ & $88.6^{\mathrm{b}}$ \\
\hline \multicolumn{5}{|l|}{ Digestive tract content } \\
\hline $\operatorname{BMP}\left(\mathrm{Nm}^{3} / \mathrm{kg}-\mathrm{VS}_{\text {added }}\right)$ & $1.076^{\mathrm{a}}$ & $0.446^{\mathrm{b}}$ & $0.361^{\mathrm{b}}$ & $0.357^{\mathrm{b}}$ \\
\hline $\mathrm{MP}\left(\mathrm{Nm}^{3} / \mathrm{kg}\right.$-Substrate $)$ & $0.273^{\mathrm{a}}$ & $0.113^{\mathrm{b}}$ & $0.092^{\mathrm{b}}$ & $0.090^{\mathrm{b}}$ \\
\hline $\mathrm{D}_{\operatorname{deg}}(\%)$ & $208.1^{\mathrm{a}}$ & $86.3^{\mathrm{b}}$ & $69.9^{\mathrm{b}}$ & $69.0^{\mathrm{b}}$ \\
\hline
\end{tabular}

${ }_{\mathrm{a}, \mathrm{b}}$ Means in the same row with different superscripts differ significantly $(\mathrm{p}<0.05)$.

${ }^{1} \mathrm{BMP}=$ Biochemical methane potential. ${ }^{2} \mathrm{MP}=$ Methane production. ${ }^{3} \mathrm{D}_{\mathrm{deg}}=$ Degree of anaerobic degradation. 
occurring during batch anaerobic digestion even though the inoculum is mainly composed of non-biodegradable organic materials. The biodegradable organic fraction remaining in the inoculum could be further degraded during batch anaerobic digestion through improved microbial activity resulting from inoculum addition to the batch reactor. The phenomena shown in this study indicate that inoculum activity may not be described by zero order reaction kinetics at low S/I ratios (below 0.1). We therefore conclude that the inoculum for BMP assay should be sufficiently stabilized not to influence biodegradability of the inoculum VS. However, the preparation of inocula containing well stabilized organic materials is not easy, and, as shown in this study, additional anaerobic degradation of stabilized inoculum VS may occur in an anaerobic reactor having high microbial activity during BMP assays. Therefore, in order to obtain a reasonable BMP value for waste biomasses, the assay should be assessed in a series of batch reactors having different S/I ratios. Further studies are needed to interpret inoculum activity and the relationship between microbial activity and inherent substrate and digestate characteristics in order to elucidate the effects of S/I ratio on methane yield.

\section{ACKNOWLEDGEMENTS}

This research was supported by Advanced Production Technology Development Program, Ministry for Food, Agriculture, Forestry and Fisheries, Republic of Korea (Project No. 312041-3).

\section{REFERENCES}

Angelidaki, I. and B. K. Ahring. 1992. Effects of free long-chain fatty acids on thermophilic anaerobic digestion. Appl. Microbiol. Biotechnol. 37:808-812.

Angelidaki, I., M. Alves, B. Bolzonella, L.Borzacconi, J. L. Campos, A. J. Guwy, S. Kalyuzhnyi, P. Jenicek, and J. B. van Lier. 2009. Defining the biomethane potential (BMP) of solid organic wastes and energy crops: a proposed protocol for batch assays. Water Sci. Technol. 59:927-934.

Angelidaki, I. and W. Sanders. 2004. Assessment of the anaerobic biodegradability of macropollutants. Rev. Environ. Sci. Biotechnol. 3:117-129.

APHA. 1998. Standard methods for the examination of water and wastewater. 20th Ed. American Public Health Association, Washington, DC

Beuvink, J. M., S. F. Spoelstra, and R. J. Hogendrop. 1992. An automated method of measuring the time course of gas production of feedstuffs incubated with buffered rumen fluid. Neth. J. Agric. Sci. 40:401-407.

Boyle, W. C. 1976. Energy recovery from sanitary landfills-a review. In: Microbial Energy Conversion (Ed. H. G. Schlegel and J. Barnea). Pergamon Press, Oxford, UK. pp. 119-138.

Chen, Y., J. J. Cheng, and K. S. Creamer. 2008. Inhibition of anaerobic digestion process: a review. Bioresour. Technol. 99:4044-4064.
Chynoweth, D. P., C. E. Turick, J. M. Owens, D. E. Jerger, and M. W. Peck. 1993. Biochemical methane potential of biomass and waste feedstocks. Biomass Bioenergy. 5:95-111.

Costa, J. C., S. G. Barbosa, M. M. Alves, and D. Z. Sousa. 2012. Thermochemical pre- and biological co-treatments to improve hydrolysis and methane production from poultry litter. Bioresour. Technol. 111:141-147.

Hansen, T. L., J. E. Schmidt, I. Angelidaki, E. Marca, J. C. Jansen, H. Mosbæk, and T. H. Christensen. 2004. Measurement of methane potentials of solid organic waste. Waste Manag. 24:393-400.

Hashimoto, A. G. 1989. Effect of inoculum/substrate ratio on methane yield and production rate from straw. Biol. Wastes 28:247-255.

Kim, S. H., C.-H. Kim, and Y. M. Yoon. 2011. Bioenergy and methane production potential by life cycle assessment in swine waste biomass. Korean J. Soil Sci. Fert. 44:1245-1251.

Lay, J. J., Y. Y. Li, and T. Noike. 1998. Mathematical model for methane production from landfill bioreactor. J. Environ. Eng. 124:730-736

Lin, J. G., Y. S. Ma, A. C. Chao, and C. L. Huang. 1999. BMP test on chemically pretreated sludge. Bioresour. Technol. 68:187192

Liu, C., B. Xiao, A. Dauta, G. Peng, S. Liu, and Z. Hu. 2009. Effect of low power ultrasonic radiation on anaerobic biodegradability of sewage sludge. Bioresour. Technol. 100:6217-6222.

Luste, S., S. Luostarinen, and M. Sillanpaa. 2009. Effect of pretreatments on hydrolysis and methane production potentials of by-products from meat-processing industry. J. Hazard. Mater. 164:247-255

Neves, L., R. Oliveira, and M. M. Alves. 2004. Influence of inoculums activity on the bio-methanization of a kitchen waste under different waste/inoculum ratios. Proc. Biochem. 39:2019-2024.

Owens, J. M. and D. P. Chynoweth. 1993. Biochemical methane potential of municipal solid-waste (MSW) components. Water Sci. Technol. 27:1-14.

Palatsi, J., J. Illa, F. X. Prenafeta-Boldú, M. Laureni, B. Fernandez, I. Angelidaki, and X. Flotats. 2010. Long-chain fatty acids inhibition and adaptation process in anaerobic thermophilic digestion: batch tests, microbial community structure and mathematical modelling. Bioresour. Technol. 101:2243-2251.

Raposo, F., C. J. Banks, I. Siegert, S. Heaven, and R. Borja. 2006. Influence of inoculum to substrate ratio on the biochemical methane potential of maize in batch tests. Proc. Biochem. 41:1444-1450.

Raposo, F., R. Borja, B. Rincon, and A. M. Jimenez. 2008. Assessment of process control parameters in the biochemical methane potential of sunflower oil cake. Biomass Bioenergy 32:1235-1244.

Rodríguez-Abalde, A., B. Fernández, G. Silvestre, and X. Flotats. 2011. Effects of thermal pre-treatments on solid slaughterhouse waste methane potential. Waste manag. 31:1488-1493.

Salminen, E., J. Einola and J. Rintala. 2003. The methane production of poultry slaughtering residues and effects of pretreatments on the methane production of poultry feather. Environ. Technol. 24:1079-1086. 
Vavilin, V. A., B. Fernandez, J. Palatsi, and X. Flotats. 2008. Hydrolysis kinetics in anaerobic degradation of particulate organic material: an overview. Waste Manag. 28:939-951.

VDI 4630. 2006. Fermentation of organic materials, characterisation of the substrates, sampling, collection of material data, fermentation test. VDI-Handbuch Energietechnik.

Veeken, A. and B. Hamelers. 1999. Effect of temperature on hydrolysis rates of selected biowaste components. Bioresour. Technol. 69:249-254.
Williams, A., M. Amat-Marco, and M. D. Collins. 1996. Phylogenetic analysis of Butyrivibrio strains reveals three distinct groups of species within the Clostridium subphylm of gram-positive bacteria. Int. J. Syst. Bacterol. 46:195-199.

Zwietering, H. M., I. Jongenburger, F. M. Rombusts, and K. van 't Riet. 1990. Modeling of the bacterial growth curve. Appl. Environ. Microbiol. 56:1875-1881. 